\title{
WOMEN IN THE MILITARY SPHERE: SOME ISSUES OF SOCIAL ADAPTATION
}

\section{MARIAM GEVORGYAN}

\section{Introduction}

In traditional societies, gender-specific stereotypes define a man as the "master," the "head," the "almighty," whereas a woman is described as a "secondary being," created from the rib of Adam. Women shared the same social position as slaves. Their main function was to run the household and fulfill their motherly duties.

Historians also tell us about the times when women played a leading role in public life. That was the era of matriarchy. We learn about this period from legends and myths that have survived until our days. In different historical periods, there have been various myths about women. Theses myths have depicted women as "witches," "female fatales," and even "superwomen." A superwoman defined a woman who is a mother, a worker, and a social activist at the same time. American sociologist E. Boulding notes that discrimination against women persists today, although often no longer clearly, but in a latent form, which is promoted by gender-role stereotypes. Thus, in society, everything is constructed around the ideas of what is "allowed" or "suitable" for a woman" and it is important to note that depending on the time those constructs are actually different. For example, the presence of women in the military service as military personnel has long been considered unacceptable or not suitable for women, but today it is one of the most progressive disciplines with a number of advantages and disadvantages.

Role and position of women in society has changed over time. In the $19^{\text {th }}-$ $20^{\text {th }}$ centuries particularly, striking changes took place in this regard. Feminists began to fight for the right to vote and have property, which was the first wave of feminism in the $19^{\text {th }}$ and early $20^{\text {th }}$ century. In the second wave of feminism from the 1960 s to $1980 \mathrm{~s}$, women fought for the right to get married whenever they wanted and not under the pressure of public opinion, to have reproductive rights, and to have equal pay and opportunities in the workplace. The third wave of feminism, which took place in the early 1990s, brought forth the fight for women to be classified as an individual and different ${ }^{2}$. Feminism waves, espe-

${ }_{1}^{1}$ Барбьери Э. Роль женщины в обществе будущего // Курьер ЮНЕСКО, 1993, январь

${ }^{2}$ Grady C. The waves of feminism, and why people keep fighting over them, explained. Available at: https://www.vox.com/2018/3/20/16955588/feminism-waves-explained-first-secondthird-fourth 
cially since the 1970 s, have begun to pay particular attention to the involvement of women in national security and national defense. This was because those who provide security and protection have an inherent advantage in other matters of governing the country ${ }^{3}$. In this context, we can conclude that the exclusion of women from the defense sector seems to be an artificial obstruction and is characterized as gender discrimination.

In this paper, we discuss some issues of contemporary military transformations. Feminist researchers have revealed significant relationships between gender stereotypes, gender inequality, and women's integration in the military. We provide also a brief summary of established discussions within feminist researchers on women's military participation. In the second part, we discuss promises and limitations of mainstreaming women into military institutions, because of UN Security Council Resolution 1325. The article presents a conceptual approaches how women get a chance to integrate into the military (combat roles), when gender stereotypes allow women to 'appear' in the arm forces, what stages of social adaptation they are going through.

\section{Gender stereotypes in contemporary societies}

Gender stereotypes defined as "Preconceived ideas whereby females and males are arbitrarily assigned characteristics and roles determined and limited by their gender"4. Gender stereotyping can affect and draw up some limits for possible growth and development of the abilities of male and female. On one hand, by stereotyping, it is possible to understand what kind of values, norms and prejudices exist towards women in the society. On the other hand, they are result of shared values, norms and prejudices.

The way women's autonomy, self-determination, social roles, and purposes are perceived determines how much the society is gender-sensitive. We live in the times when constitutions of most countries guarantee equal rights for men and women. Women are involved in almost every sphere of activity, the economic life of society, they have the right to vote and have access to education.

In 1893 in New Zealand, women won the right to vote for the first time, which was immediately followed by Austria (1902), Finland (1906), Norway (1919), Ireland (1922), France, Italy, Hungary etc ${ }^{5}$. Another important step that democratic countries have taken in overcoming gender inequality is the enforcement of the principle of gender justice to ensure real gender equality. Gender equality became a fundamental human rights principle enshrined in binding human rights treaties.

Another significant event took place in 2000 when the UN Security Coun-

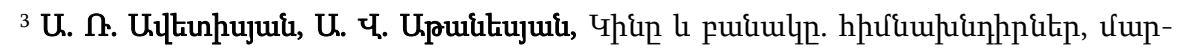

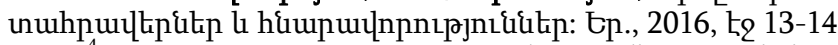

${ }^{4}$ Gender Equality Glossary, Gender Equality Commission of the Council of Europe, 2015.

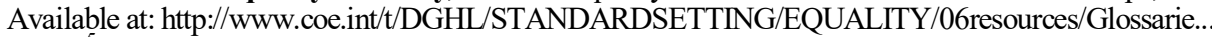

${ }^{5}$ See more at: http://archive.ipu.org/wmn-e/suffrage.htm 
cil adopted Resolution 1325 on women, peace and security. Although a lot has been done in general, the promise and potential of UNSCR 1325 remains unfulfilled. This is especially true in the field of military operations, which remains a largely male-dominated area that continues to be held back- in both effectiveness and equal opportunity.-bureaucratic and resource barriers ${ }^{6}$.

It is worth mentioning that several international human rights instruments forbid discrimination on grounds of gender and promote de jure integration. Article 15.1 of the Convention on the Elimination of All Forms of Discrimination against Women (CEDAW), adopted in 1979 by the UN General Assembly, states that all "States Parties shall accord to women equality with men before the law". 7 The CEDAW Committee has also adopted a comment on Articles 7 and 8 of the Convention that looks specifically at participation of women in the military ${ }^{8}$.In the context of all this, it should be noted that a number of states should address the issue of women's involvement on the constitutional level, thus, avoiding a number of problems connected with the triangle of citizenship - military service - gender issues. For example, Article 14.3 of the Armenian Constitution states: "Every citizen shall be obliged to take part, as prescribed by law, in the defense of the Republic of Armenia"". But the subtle difference here is that if the service is mandatory for men, it is optional for women, and only on a contractual basis. All this sounds very attractive and makes an impression of equality, but de facto there are a number of issues that need to be resolved in this area.

\section{Feminism and gender militarization}

The end of $19^{\text {th }}$ century Military service as a field of employment gradually opened its doors for female staff (at least in legal terms). It brought new discursions in societies whether women should or should not serve in the army. From the 1970s, the debate has been conducted between two rather different political positions. On one hand, there have been those arguing for the 'right to fight,' emphasizing women's equality with men. On the other, anti-militarist feminists have argued that women's military participation (however manifest) merely legitimizes an institution, which is antithetical to the goals of feminism ${ }^{10}$.

Liberal Feminism (equality as sameness): Liberal feminists fighting for equality under the law, equal standards and opportunities for men and women.

\footnotetext{
${ }^{6}$ Verveer M., Women and Gender Perspectives in the Military: An International Comparison. Edited by Egnell Robert and Alam Mayesha. Washington, DC: Georgetown University Press, 2019, p.1-3.

Convention on the elimination of all forms of discrimination against women Article 1, New York, 18 December 1979, Available at https:/www.un.org/womenwatch/daw/cedaw/.

${ }^{8}$ Implementation of Article 21 of the Convention on the Elimination of All Forms of Discrimination against Women: Analysis of articles 7 and 8 of the Convention", CEDAW/C/1994/1, Available at: https://www.un.org/docu-ments/ga/cedaw/13/cedawc1994-4.htm.

${ }^{9}$ Article 14.3 of the Constitution of RA, Available at:https:/www.president.am/en/constitution-2015/

${ }^{10}$ Duncanson C., Woodward R., Regendering the military: Theorizing women's military participation. Security Dialogue, 2015, p. 4.
} 
This is the track that the Canadian military was forced to follow with the passing of the Canadian Human Rights Act (Winslow and Dunn 2002) ${ }^{11}$. Proponents of this approach argue that all military posts should be available to women, and the standards of physical fitness and training should be the same for both gender.

Cultural feminism (equality as recognition of difference): Cultural feminists accept the differences between men and women; moreover, they see women generally in peace support operations. Critics of this approach state that this view only reinforces gender stereotypes.

Radical feminism (equality as anti-subordination): Radical feminists want to free women from all subordinate roles resulting from patriarchy ${ }^{12}$. They criticize Cultural and Liberal feminists, specially, claiming that Cultural feminists' views reinforce gender stereotypes in society. Radical feminists have played a major role in raising the issue of sexual harassment of women in the armed forces. As they state sexual harassment has big impact on depriving women of jobs, status, and self-respect. Moreover, what is important to take into consideration that those effects are as much psychological as physical ${ }^{13}$.

Postmodernist feminists (rejection of unitary paradigmatic approaches): Postmodernist feminists see gender not as an "essence" but more as performance, constructed in the moment by the social actors present ${ }^{14}$. Postmodernist feminism's followers raise the issue of biological differences between men and women because as sociologists state sex and gender are socially constructed. In addition, technological development brings societies to the level where physical differences between genders have been blurred. Thus, we can state that gender identity in the military will be shaped as society shapes the differences between women and men.

Nevertheless, Anti-militarist feminists suggest that an increase in women's military participation is neither progressive for women, nor for a more peaceful international order ${ }^{15}$. They state that women will never be equal in the military sphere, moreover, discrimination in the workplaces, inaccessible combat roles, and lack of access to high positions, abuse, sexual harassment and violence and complexity of military training emphasize and deepen gender inequality and discrimination ${ }^{16}$.

Despite all these approaches, supports and criticisms, the armies of the world accept women into their ranks. In 1997, women were allowed to serve in US aerial

${ }^{11}$ Winslow D. Gender and Military Sociology, Swedish National Defence College, Department of Leadership and Management, pg.8, Available at: https://pdfs.semanticscholar.org/ 8e46/220715509f02bab3e93207473d5e653ed74b.pdf

${ }^{12}$ Winslow D. Gender and Military Sociology, Swedish National Defence College, Department of Leadership and Management, pg.9, Available at: https://pdfs.semanticscholar.org/ 8e46/220715509f02bab3e93207473d5e653ed74b.pdf

${ }^{13}$ Zeigler S. L., Gunderson G. G., Women and the U.S. Military. Lanham, MD: University Press of America, 2005, p. 6.

${ }_{15}^{14}$ Winslow D., Gender and Military Sociology, ibid.

${ }^{15}$ Duncanson C., Woodward R., Regendering the military: Theorizing women's military participation. Security Dialogue, 2015, p. 5.

${ }^{16}$ Ibid p. 5-7. 
and naval combat, and in 2015 Pentagon allowed women stand for front-line ground combat positions as well. In Israel, women not only serve in combat units but lead them, too (from 1985 women have officially allowed to take up combats roles). India has also jumped on the equality bandwagon; its Supreme Court recently passed a ruling allowing women to serve as army commanders ${ }^{17}$. Germany in 2001 opened combat units for women. Currently, women serve across all units including onboard jet fighters, submarines and as paratroopers. Norway allowed women to serve in the army since 1938 but some political changes in 1947 confined women to serve. In any case, since 1985, Norway became the first NATO nation to allow women to serve in combat roles. In 2014, Norway also set up the Hunter Troop - the world's first all-female Special Forces training programme ${ }^{18}$. Canada opened all military occupations to women in 1989, with the exception of submarine service, which opened in $2001^{19}$.

It is worth mentioning also the factors which make women take part in military jobs. M. Segal in her "Women's military roles cross-nationality: past, present and future" ${ }^{20}$ suggests a model to identify and measure the objective and subjective factors determining the environment surrounding the level and probability of women's enlistment. As Segal notes, the role of women in the military is mainly based not only on the objective reality but also on subjective (cultural) determinants. She states that women's military roles are socially constructed ${ }^{21}$ and every society gives chance to women only when it is considered extremely needed. Unfortunately, society has a short memory and after the elimination of the threats, it forgets about women's support and takes them back to their homes or to other female jobs.

The model recommended by $\mathrm{M}$. Segal consists of three main components: military, social structure and culture ${ }^{22}$. Each component has sub-elements, which are in complex relations with one another. These factors work together and a change in one brings changes in the others. It should be noted that the political aspect directly affects the goals, structure and policy of the military sector. The military personnel is formed from the society members of a country; therefore, presumably, they reflect the values and norms of that society.

The involvement of women in the military is highly encouraged, particularly in situations when a country has conflicts, wars or is in a deep internal crisis. In such situations, the management of human resources and the uninterrupted implementation of work become central to society.

According to Segal, the role of women in the military becomes important

${ }^{17}$ Goldring K., Should women serve in the combat unites, Available at: https://www. theperspective.com/debates/living/women-serve-combat-units/

${ }_{18}^{18}$ See more at: https://www.nato.int/ims/2001/win/norway.htm

${ }^{19}$ See more at: https://forces.ca/en/women-in-the-caf/

${ }^{20}$ Segal M. W., Women's Military Roles Cross-Nationality: Past, Present and Future. Gender and Society, 9 no. 6, 1995, p. 757-775.

${ }^{21}$ Ibid. p. 761 .

22 Ibid. p. 759 . 
and necessary when society's military culture changes, society is tolerant of women's military roles, women agree to accept the changes needed to match their new lifestyle, and when society facing with national security threats ${ }^{23}$.

Iskra, S. Trainor and M. Leithauser state that although Segal's model is useful and working it needs some additional block to be complete: the political aspect. Thus, it is impossible to have any progress in the non-traditional sphere for women without political support and favourable circumstances ${ }^{24}$.

\section{Peculiarities of social adaptation in the Military}

Military service is a specific profession. The role of the servicemen is determined by their military responsibilities and obligations. From the day of joining the army, their values, activity and behaviour are shaped and limited by the characteristics of their careers and society.

"Social adaptation is one of the mechanisms of socialization that allows a person (group) to actively engage in various structural elements of the social environment by standardizing repetitive situations, which makes it possible for a person (group) to function successfully in a dynamic social environment." ${ }^{25}$

In general, the adaptation in the military sphere is carried out in three stages: pre-military, military and post-military. Here it is important to take into account the socio-cultural context, which on one hand helps, on the other hand, hinders the process of social adaptation ${ }^{26}$.

The pre-military phase takes place in the life of every person (mainly boys, depending on the gender requirements of the military job in the country) and aims to prepare them for possible wars. In times of war, millions of young people will go through the military phase. The main sub-stages of this are a transfer of knowledge about the army, basic physical training, specialized training, technical training, preliminary combat training, military operations, and finally postwar period and demobilization.

The last or post-war stage is not defined by any strict characteristics. The only characteristic is that the person who has survived the above-mentioned two stages receives the social and legal status of a veteran and is involved in the post-war phase ${ }^{27}$.

According to A. Atanesyan, there are "soft" and "hard" versions of social adaptation in the military staff. In case of a "hard" version of adaptation to the military service, the serviceman is mostly isolated from his former social relations, subject to strict rules and regulations. This form is derived from the requirements of the military situation. The "soft" version of the adaptation al-

${ }^{23}$ Segal M. W., ibid.

${ }^{24}$ Iskra, D.M., Trainor, S.C., Leithauser, M., \& Segal, M.W., Women's Participation in Armed Forces Cross-Nationally: Expanding Segal's Model. Current Sociology, 50, 2002, p. 771 - 797.

${ }^{25}$ Завьялова Е. К., Психологические механизмы социальной адаптации, Вестник Балтийской педагогической академии. Вып. 40. СПб., 2001.

${ }^{26}$ Hollingshead A. B., Adjustment to Military Life, American Journal of Sociology , Mar., 1946, Vol. 51, No. 5, Human Behavior in Military Society (Mar., 1946), pp. 439-447

${ }^{27}$ Ibid, p. 439. 
lows the soldier's connections and active contacts with people within his social environment. In this case, it is possible to avoid the high "cost of human losses".

In reference to women's adaptation, it is important to speak about women's adaptation it is important to specify which type of involvement we are speaking $^{28}$.

The specificity of the adaptation of military personnel to service is a twoway process of interaction between the individual and the collective, mediated by joint military activity, the result of which is the adaptation of the individual and its acceptance by the collective ${ }^{29}$.

Social adaptation and social inclusion can vary depending on whether a female is in the role of combat service or in administrative service. It is obvious that in the military sphere, men outnumber women and it could bring problems connected with gender discrimination, various forms of violence, problems with WCs, locker rooms, even dress codes and behavior. Everything is more complicated when speaking about women in combat roles. Women who have selected "masculine" roles have a special and distinguished scope of interests. In many discussions, male officers who are against women's involvement in combat roles state that young soldiers should follow the example of strong, wilful and unbreakable commanders. According to these officers, women are not suitable for these roles. This way of thinking, unfortunately, is not rare and it puts women in a more difficult situation during adaptation.

During their career women face a number of social adaptation problems connected with:

- Female staff- self-perception, intergroup communications, socialpsychological and status problems, personal and family life difficulties.

- Male staff- getting respect, stereotypical thinking, fighting for being recognized as a fully loyal member of military personnel, existence of different types of violence, and gender discrimination.

- Public perceptions- socially structured gender roles, stereotypes, difficulties with combining different social roles.

- Military accommodation- conditions of accommodations, workplace conditions, and distance from home.

- Legal aspect- lack of laws for women's military service, lack of institutionalized information ${ }^{30}$.

Military personnel go through a social adaptation process and must adapt in three ways: realize the role of a military person, get used to a special lifestyle

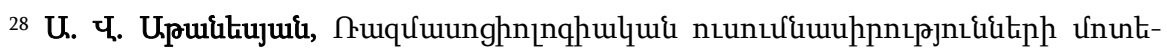

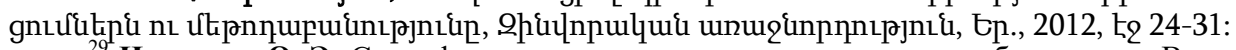

${ }^{29}$ Неронова О. Э. Специфика адаптации военнослужащих к службе в армии, Воронежский государственный университет, Доступно: file:///C:/Users/User/Desktop/ spetsifikaadaptatsii-voennoslujashih-k-slujbe-v-armii.pdf

${ }^{30}$ Atanesyan A., Women in Armenian Armed Forces: self-perception and opportunities for the better recruitment and adaptation policies, Center for Gender and Leadership studies, 2014, p. 4-5, http://www.ysu.am/files/Arthur\%20Atanesyan.pdf 
as a group, and get used to special military operations. They should carry out the role with high professional standards recognized by the public and male experts. It requires the ability to master team spirit, have great leadership skills, high self-confidence, honesty, a strong sense of duty and obligation, and selfpride. All of these are the main characteristics of an ideal soldier ${ }^{31}$.

The military lifestyle is mainly characterized by duty and a high level of risks. In fact, under certain circumstances, military lifestyle changes with development processes. During different historical periods, there have been different types of armies but the underlying concept of a group, a team has always been as important as it is today. Of course, a team can be considered successful if interpersonal relationships and communications are on a high level. J. Yang and $\mathrm{M}$. Yu revealed three promoting and three behavioral factors influencing interpersonal relationships. These factors allow individuals the opportunity to explore and understand themselves and to achieve satisfaction in interpersonal relationships. The three promoting factors include sympathy (the ability to look at the world from others' point of view and to appreciate others' experiences and feelings), mutual understanding (the ability to understand one's own as well as others' feelings or experiences), and reality (the ability to respect and accept reality). The behavioral factors teach an individual to be respectful and to have good manners. This particular factor includes honesty (the ability to interact with others in an honest and positive way), respect (the ability to care about and trust others with a passion), and service (the ability to share others' feelings and experiences and to serve them $)^{32}$.

To sum up, we may say that women's acceptance into the service- and support-based positions, has been slow but steady. No one can say if this tendency will grow rapidly or decrease dramatically, but the numbers show steady progress. Every country must understand that it is a part of a global system and cannot stay away from the global tendencies. Today one of the most controversial topics in democratic civil-military relations is the integration of women into the military.

Finally, to support our statements with more facts let us look at the numbers of women in Active Duty military personnel in the armed forces of NATO member states, as well as Russia, India and China as states with big armies (with the exception of Iceland that does not have armed forces) in 2017. The average percentage of women in the armed forces of each NATO member nation is $11.1 \%$, which indicates an increase of $0.2 \%$ compared to 2016 when it was $10.9 \%{ }^{33}$.

According to the officials of the Ministry of Defense of Armenian, in 2017

${ }^{31}$ Jianxin Yang and Min Yu, Military Men and Women Facing Challenges of Adapting to New Military Environment, Asian Social science, vol 5, n. 3, 2009.

32 Ibid. p. 73-75.

33 Summary of the National reports of NATO member and partner, Nations to the NATO committee on gender perspectives, 2017, p. 16. 
there were more than 2,000 women working in the ministry, compared with roughly 1,400 in 2012 , which is approximately $4 \%$ of the staff. The vast majority of women hold clerical positions or serve in medical services and communication units. But there seem to be more and more women in combat roles too, notably snipers and sappers ${ }^{34}$.

Thus, it is necessary to create relevant social, cultural, legal norms for faster and unimpeded implementation of these processes.

Key words: women in military, social adaptation, female military staff, integration models

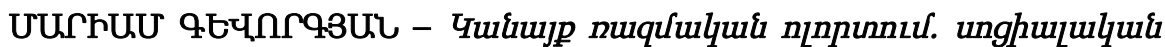

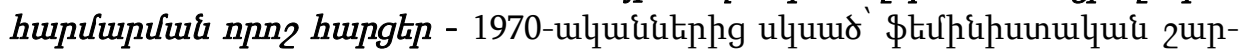

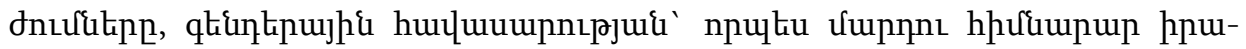

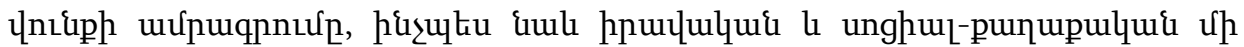

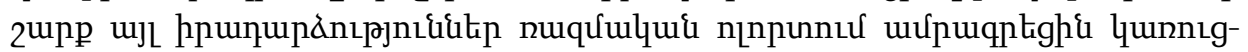

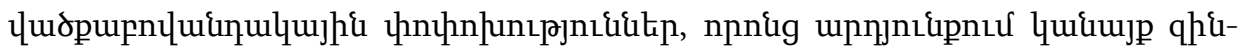

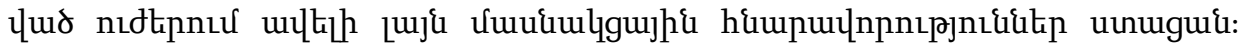

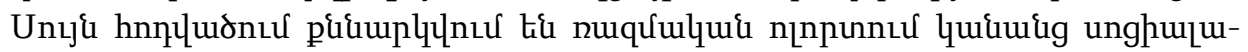

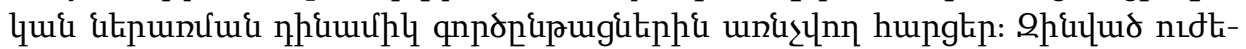

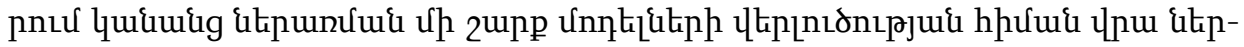

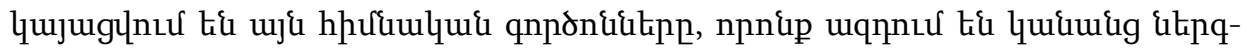

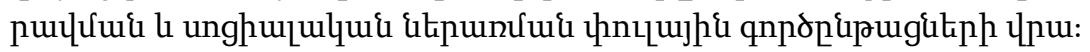

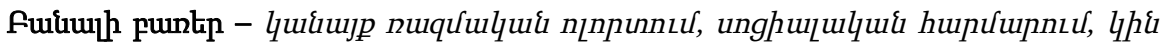

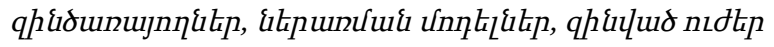

МАРИАМ ГЕВОРГЯН - Женщины в военной сфере: некоторые вопросы социальной адаптации. - Начиная с 1970-х годов феминистские движения и признание гендерного равенства одним из основных прав человека, а также ряд других юридических, социально-политических изменений в вооружённых силах зафиксировали существенные структурные сдвиги, которые предоставили «слабому полу» более широкий доступ в эту сферу. В статье рассматриваются вопросы, связанные с динамическими процессами социальной интеграции женщин в армейской среде. На основе анализа ряда моделей их вовлечения в вооружённые силы представлены основные факторы, влияющие на поэтапные процессы такого вовлечения в эту специфическую сферу.

Ключевые слова: женщины в военной сфере, социальная адаптаџия, женщинывоеннослужащие, модели интеграџии

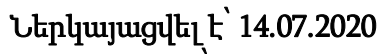

Qpupunultil t' 16.09 .2020

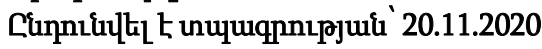

\footnotetext{
${ }^{34}$ Danielyan E., Armenia: Boosting Female Presence in Army, Eurasianet, 2017. Available at: https://eurasianet.org/armenia-boosting-female-presence-in-army
} 


\begin{abstract}
Since the 1970s, feminist movements and the recognition of gender equality as one of the basic human rights, as well as a number of other legal, socio-political changes in the armed forces have recorded significant structural changes that have provided the "weaker sex" with wider access to this area. The article deals with issues related to the dynamic processes of social integration of women in the army environment. Based on the analysis of a number of models of their involvement in the armed forces, the main factors influencing the stage-by-stage processes of such involvement in this specific area are presented.
\end{abstract}

Keywords: women in military, social adaptation, female military staff, integration models

\title{
About Authors
}

Mariam Gevorgyan - PhD student of the Chair of Applied Sociology, Yerevan State University E mail: mariamgev94@gmail.com

\section{REFERENCES}

Barb'eri, E. (1993). Rol' jenshchiny v obshchestve budushchego. Kur'er YUNESKO

Grady, C. (2018). The waves of feminism, and why people keep fighting over them, explained. Retrieved from https://www.vox.com/2018/3/20/16955588/feminism-waves-explained-firstsecond-third-fourth

Avetisyan, A.R. \& Atanesyan, A.V. (2016). Kiny ev banaky: himnakhndirner, martahraverner ev hnaravorutyunner. Yerevan, 13-14

Verveer, M. (1979). Women and Gender Perspectives in the Military: An International Comparison. Edited by Egnell Robert and Alam Mayesha. Washington, DC: Georgetown University Press, 1-3

Duncanson, C. \& Woodward, R. (2015). Regendering the military: Theorizing women's military participation. Security Dialogue, 4. Doi: https://doi.org/10.1177/0967010615614137 Winslow, D. (2010). Gender and Military Sociology, Swedish National Defence College, Department of Leadership and Management, 8. Retrieved from https://pdfs.semanticscholar.org/8e46/220715509f02bab3e93207473d5e653ed74b.pdf Zeigler, S. L. \& Gunderson, G. G. (2005). Women and the U.S. Military. Lanham, MD: University Press of America, 6

Goldring K., Should women serve in the combat unites, Retrieved from https://www.theperspective.com/debates/living/women-serve-combat-units/

Segal, M. W. (1995). Women's Military Roles Cross-Nationality: Past, Present and Future. Gender and Society, 9 no. 6, 757-775. Doi: https://doi.org/10.1177/089124395009006008 Iskra, D.M., Trainor, S.C., Leithauser, M., \& Segal, M.W. (2002). Women's Participation in Armed Forces Cross-Nationally: Expanding Segal's Model. Current Sociology, 50, 771 - 797. Doi: https://doi.org/10.1177/0011392102050005009

Zavyalova, E.K. (2001). Psikhologicheskie mekhanizmy social'noi adaptacii. Vestnik Baltiiskoi pedagogicheskoi akademii. 40, St. Peterburg 
Hollingshead, A. B. (1946). Adjustment to Military Life, American Journal of Sociology. Human Behavior in Military Society. Vol. 51, No. 5, 439-447. Doi:

https://doi.org/10.1086/219855

Atanesyan, A.V (2012). Razmasociologiakan usumnasirutyunneri motecumnern u metodabanutyuny, Zinvorakan arajnordutyun, Yerevan, 24-31

Neronova, O.E. (2014). Specifika adaptacii voennoslujashchikh k slujbe v armii, Vestnik Voronejskogo gosudarstvennogo tekhnicheskogo universiteta T 10 No3-2, 58-59

Atanesyan A. (2014). Women in Armenian Armed Forces: self-perception and opportunities for the better recruitment and adaptation policies, Center for Gender and Leadership studies, 4-5. Retrieved from http://www.ysu.am/files/Arthur\%20Atanesyan.pdf 